\title{
The Effects of Reciprocal Style on Junior Secondary \\ Students' Learning Interest, Collaboration Skill and Communication Skill in Volleyball Lessons 互惠式排球教學對初中學生之學習興趣、協作能力及溝趩能力的影響
}

\author{
Chi Yung LAM Alberto CRUZ \\ Department of Health \& Physical Education, \\ The Hong Kong Institute of Education, HONG KONG
}

林志勇＼cjkstart高達倫

香港教育學院健康與體育學系

\begin{abstract}
Mosston and Ashworth (1994) introduced the spectrum of teaching styles in physical education. Research findings indicated that reciprocal teaching style brought positive benefits to student learning. This study aimed at examining the effects of reciprocal style on junior secondary students' learning interest, collaboration skills and communication skills in volleyball lessons. Participants were 32 female junior secondary students and they were taught in ten volleyball lessons with reciprocal teaching style. Mixed methods were employed to collect both quantitative and qualitative data in the study. The collaboration skill and communication skill analysis checklists, participant observation field notes and individual interview were used as to understand the learning process and the students' perceptions on the teaching style within the lessons. Findings indicated that there were positive effects on students' learning interest, collaboration and communication skills under this teaching style. Results were discussed in the following aspects: (1) how did the students enhance learning interest, (2) how did the students develop collaboration skills, and (3) how did the students develop communication skills under this teaching style. The findings of this study have implications on the practice of physical educators.
\end{abstract}

\section{摘要}

本研究旨在探討互惠式排球教學對學生的學習興趣、協作能力及溝通能力的影響。三十二位女學生接受十堂互惠式排球課。 透過協作及溝通能力分析表、參與式觀察及個人訪談, 了解學生的學習過程及對此模式的感受及意見。結果顯示此教學法對學生 的學習興趣、協作及溝通能力都有正面的影響。討論包括此教學法：（一）如何提升學生學習興趣；（二）如何發展學生協作能 力; 及 (三) 如何發展學生溝通能力。研究結果帶給體育教師教學啓示。

\section{引言}

現今「學校課程必須協助學生建立正確的價值觀和態 度，貫徹終身學習的精神，從而學會如何學習; 培養各種共 通能力, 以便獲取和建構知識, 奠定全人發展的基礎」（課 程發展議會, 2001, 頁4）。這正指出現今的教育, 已不再 是強調知識的直接傳授, 而是在於如何協助、促進學生的學 習。
但是, 反觀傳統的體育教學, 大都以技能教學為主, 其 主要的教學模式都是由教師直接示範及講解, 而當中學生的 學習往往都只是處於很被動的狀態, 故學生亦缺乏學習興趣 (Reppa，2007；蔡宗達，2004）。看來以往的體育課於教 改下, 必須改變才能迎合新的課程目標及解決學生學習興趣 的問題。 
體育科在配合課程目標下，也不僅是著重技巧的傳授， 亦需肩負起啟發學生思維及發展不同共通能力的責任, 此等 也是為學生將來投入社會作好準備。而協作、溝通、創造及 批判性思考四種共通能力是體育科特別注重發展的（課程發 展議會，2002）。

然而, 在中學階段的青少年 (即初中學生) 正處於人際 關係發展的重要時期（Beveridge \& Berg，2007；姚愛梅， 2008），教師有責任在這個時期幫助他們發展人際關係。而 學校體育關注發展學生的協作能力及溝通能力, 正是幫助初 中學生學習如何建立良好人際關係, 故學校體育能協助學生 發展人際關係。更重要的是, 學校體育幫助初中學生發展協 作能力及溝通能力既可以配合課程教革後的要求, 亦切合學 生成長需要。但是, 學校體育能如何協助或影響學生發展此 方面的共通能力呢?

\section{互惠式教學模式}

Mosston教學光譜原理認為「教學行為是一連串的 決定, 決定者由教師與學生按情況而分擔並扮演之」

(Mosston \& Ashworth, 1994) 。Mosston教學光譜主要分 為十一種教學模式, 包括 : 命令式、練習式、互惠式、自測 式、包含式、導引式、擴散式、創造式、集中式、設計式及 自教式。這十一種教學模式可以分為兩大群組（Cluster）， 前五種屬於「再製」(Reproduction) 的類型, 主要由教師 主導的, 亦稱「直接教學法」; 而後六種則屬於「生產」

(Production) 的類型, 主要由學習者主導, 而教師只是 從旁協助, 亦稱「間接教學法」（Mosston \& Ashworth, 1994）。

互惠式教學模式是同儕學習 (Peer-tutoring) 的一種, 可以雙人學習或小组形式進行, 常以 2 人為一組, 按教師預 先設計的活動, 一位學生練習活動內容, 另一位學生作觀察 者, 並向練習者給予回饋, 動作完成後交換角色。而教師的 工作主要是事先設計活動內容及動作標準卡, 在課堂扮演輔 助的角色, 不給予練習者關於技術動作的回饋, 轉移對觀察 者的行為表現作出觀察及回饋（周宏室, 1994）。

互惠式教學模式將決定權轉移到學習者身上, 使學習 者擁有部分的學習決定權, 學習者間互相提供回饋, 除了技 能的學習外, 也獲得更多人際溝通機會 (Mosston \& Ashworth，2002）。而學習者擁有更多學習決定權時, 亦表示 他們擁有更多自主權, 這樣他們會更有動力去學習, 大大 提升他們的學習興趣 (Vallerand, Pelletier, \& Koestner, 2008) 。
Byra（2006）研究指出學生在互惠式教學模式下, 得到 一個正面及享受的學習環境。學生擁有更多學習權, 便覺得 課堂更有挑戰性, 並更加投入學習, 這些對學習者的學習動 機都有正面的作用。

Jackson和Dorgo（2002）指出教師的教學受到很多的限 制, 如：學生差異、用具的多少、教師的回饋次數等等。這 些限制使教學效能降低, 但互惠式教學法則令很多限制問 題迎刃而解。在此教學模式下學生需與其他同伴合作, 並一 起學習, 這不但能減輕教師的教學負擔, 提高學生的學習興 趣, 並推動他們的社交互動。他們認為互惠式教學法能提高 學習效能及有助學生社交方面的發展。

Donnelly（2002）亦指出互惠式教學法可以有效幫助學 生改善溝通能力及訓練學生幫助其他同伴。因為學生在此教 學模式下需要扮演「小老師」的角色, 負責給予同伴回饋, 這樣能夠提供機會鍛鍊他們的溝通能力, 並擔起協助同伴學 習的責任。

Goldberger（2006）研究指出於互惠式教學模式下的學 生對同伴是較有同理心、讚賞及鼓勵。至於回饋方面, 於此 教學模式下的學生會提供更有效的回饋及向同伴要求更多的 回饋。

至於組合效果方面, 研究顯示學習者與較熟悉的同伴 一組比與不太熟悉的人一組時學習情況有分別。觀察者會 給予更多回饋，而練習者更舒服去接納回饋；至於學習者的 能力對於他們給予或接納回饋的多少及舒適度是沒有影響的 (Byra \& Marks, 1993) 。

Ernst和Byra（1998）探討學習者在互惠式教學方法下怎 樣學習才最有效。他們發現所有學習者在技能學習方面有改 善, 而低能力的學習者無論跟甚麼能力的學習者一組都是獲 得最大的改善。至於認知方面, 所有學習者都有改善, 而無 論跟甚麼能力的學習者一組都是沒有明顯差異的。這種社會 化的教學模式能使技能及認知學習都同樣有幫助, 而給予及 收取回饋對於學習者是一個正面的經驗, 對社交發展有所裨 益。

看來互惠式教學法應能讓學生更有興趣投入課堂學習, 及對發展學生的協作能力及溝通能力有所幫助。但翻查文 獻, 於香港進行互惠式教學方法的研究甚少, 而這種教學模 式在香港環境下能否同樣產生正面效果? 因此, 研究者欲探 討互惠式排球教學如何影響初中學生之學習興趣、協作能力 及溝通能力。為了達到上述目的, 本研究定下三個研究問題 引導整個探究過程 :

一、互惠式教學模式對初中學生的學習興趣有何影響？

二、互惠式教學模式對初中學生的協作能力有何影響?

三、互惠式教學模式對初中學生的溝通能力有何影響? 


\section{研究方法}

\section{研究對象}

是次研究進行前都得到研究對象及其學校同意。本研究 參與對象是香港新界北區一所中學中三級女生, 一共32人, 年齡介乎 13 至 14 歲。她們會接受為期 5 周, 一共 10 課節, 每 課節為 40 分鐘的互惠式排球教學。上課時她們會以小组形式 學習, 每組約 4 人。Ernst和Byra（1998）指出在互惠式教學 模式中, 學生能力之高低不影響其社交方面的效果, 最重要 是按學生喜好選擇同伴。故此, 分組方法是全由她們自由組 合。學習時, 2 人為練習者, 其餘 2 人為觀察者, 負責提供回 饋。完成練習後, 交換角色, 以達互相教學之角式輪替。

\section{研究工具}

本研究主要採用的研究工具包括：(一) 參與式觀 察、（二）田野筆記、（三）協作能力及溝通能力分析表、 (四) 半結構式訪談與 (五) 互惠式教學行為檢核表。參與 式觀察是以收集互惠式教學情沉的資料。田野筆記是記錄觀 察所得, 作為教學情沉的證據, 並於分析時用作探索更多問 題之用。學生對互惠式教學的觀感則透過個人訪談取得。而 學生的協作及溝通能力之變化情沉會以協作能力及溝通能力 分析表的前後測試比較作了解。互惠式教學實施與否則以互 惠式教學行為檢核表作檢定。三角測量法用以檢定不同蒐集 資料方法所得的結果之一致性, 而資料的可信度及可靠度亦 因資料的多元化來源得以加強（李曉風、余雙好, 2006）。

\section{資料菟集}

研究者擬定研究計劃, 設計教學計劃, 以單元內容配合 初中排球課程, 而教學內容如表 1：

表1：教學內容

\begin{tabular}{|c|c|}
\hline 周次 & 敎學內容 \\
\hline 一 & 下手傳球 \\
\hline 二 & 下手發球 \\
\hline 三 & 上手傳球 \\
\hline 四 & 上手發球 \\
\hline 五 & 接發球 \\
\hline
\end{tabular}

在實驗教學開始前, 首研究者先解釋是次研究的目 的, 要求學生填寫一份與協作及溝通能力有關的學習者分析 表。在實驗教學完結後, 要求學生再次填寫此分析表。所 採用的分析表是由許否 (2008) 編制而成, 用以測量學習 者在合作和溝通方面的主動意識和課堂表現, 有利於教師 們更了解學生, 為後續的教學設計提供依據。同時, 該表
也有利於在課程結束後對比學習效果。以了解此教學法對 學生協作及溝通能力的影響。而受試者填畢該表後, 該表 結果接受Cronbach's alpha的信度測試, 各項問題間之相關 係數在 0.8 以上, 這表示其信度符合內在一致信度 (Internal consistency reliability）。根據謝旭洲（2008），其相關係數 需要是 0.7 或以上才是接受水平, 而全部結果都是 0.8 以上, 符合標準。問卷題目一共有 17 題, 內容主要是：(一) 學生 怎樣協作、（二）學生協作時的態度、（三）學生怎樣溝 通、（四）回饋的情況怎樣、（五）學生對回饋的態度。而 該量表採用正向計分, 「從未如此」計1分至「總是如此」 計5分, 得分越高表示相關的能力越強。這分析表數據結果 亦用以支持訪談資料的真實性及可靠性。

整個教學期間, 研究者都會作參與式觀察, 以同學協 助同伴練習及提供回饋的情沉為觀察重點, 課後並立即製 作田野筆記以記錄觀察所得的資料。而為了破保所實施的互 惠式教學真確性, 研究者透過兩位觀察員利用互惠式教學行 為檢核表來檢察所實施的互惠式教學。教學行為檢核表為 Sherman（1982）研究出來的互惠式教學行為檢核表, 兩位 觀察員檢核得出的結果需有八成或以上的同意度才算達標。 而由兩位檢測員得來的結果分別是 $88 \%$ 及 $82 \%$, 符合標準。

另外, 在課後研究者亦會隨機抽出十位同學進行訪 談。訪談目的是以了解學生對互惠式的觀感及其學習時的 協作和溝通情況。而訪談都會遵守一般的訪談指引 (Patton, 2002）。本研究採用半結構的訪談方式, 其訪談大綱是由 一系列問答題組成, 引導受訪者具體的回答, 搜集廣泛且 較有系統性的資料（王文科，2000）。訪談問題是根據為了 解體育學習成果架構（課程發展議會, 2005) 對評估共同能 力的行為例子撰寫而成, 內容主要是：(一) 學生對互惠式 的興趣與感覺、（二）學生的協作情況、（三）學生的協作 態度、（四）學生的溝通情沉、（五）學生提供回饋的情 況、(六) 學生提供回饋的態度。而訪談問題事前由一位具 質性研究專長的大學體育學者進行審評, 以確保內容效度

(Patton, 2002)。另外, 研究者亦邀請該研究中學同級五 位同學進行先導測試（Pilot study），並以受試者的角度去 檢視訪談問題是否語意不清, 了解問題的內容和結果是否 配合所定研究問題, 以修訂訪談問題 (Fraenkel \& Wallen, 2003）。最後, 受試學生對於訪談問題都沒有特別意見。整 個訪談保持在三十分鐘之內, 以免時間太長而引至受訪者 疲累及集中力下降, 影響訪談的真實性 (Gratton \& Jones, 2004）。至於每次的訪談, 研究者都以錄音機 (MP3) 記 錄訪談內容, 以幫助保留資料的原貌 (Patton, 2002)。最 後, 將整個訪談內容製作成逐字式文字稿。 


\section{資料分析}

研究者採用SPSS 17套裝軟體將學習者分析表所得的 數據進行統計分析。具體分析內容包括：(一) 採用描述 性統計資料（Descriptive statistics）顯示協作能力及溝通能 力分別的總分、平均值、最大值及最小值等數據；(二) 採用相依樣本的t檢定 (Paired samples t-test) 作協作能力 和溝通能力的全班結果前測與後測分數比較, 根據謝旭洲 (2008），是次顯著度為0.01或以下才是接受水平。

接著, 研究者將訪談內容轉成逐字式文字稿, 作為分析 所用的第一手資料（Raw data），並提高信度（李曉風、 余雙好, 2006）。而研究者會採用「持續比較法」（Constant comparison method) (Strauss \& Corbin, 1990) 分析蒐 集得來的資料。研究者會將目前所得的資料不斷地與前次分 析所得的資料相互比較, 一來可以更熟悉資料內容, 二來反 覆的比較有利於作出更完備的分析。在資料分析步驟中, 研 究者反覆熟讀訪談的逐字式文字稿及田野筆記, 試圖進入並 了解受訪者的個人世界, 以達致最全神的演繹及詮釋。之後 研究者再畫出重要敘述句, 將所得到資料, 經過比較、歸納 來分門別類, 並發展主題, 綜合每一位受訪者的分析結果。 研究者再比較討論所分析的結果以達致共識。

最後, 研究者為免於資料分析過程出現與所菟集資料 發生主觀性與論點之偏頗, 故於資料分析及推論過程, 研究 者要求研究參與者對研究者所詮釋與分析容, 進行確認與檢 視, 以確保資料分析的客觀性與真實性（Patton，2002）。

\section{結果與討論}

本研究旨在探討互惠式排球教學對學生的學習興趣、 協作能力及溝通能力的影響。以下是根據所得的結果進行分 析及討論。主要分為3個方向：一、互惠式教學對於學生學 習排球的興趣之影響; 二、互惠式教學對學生協作能力之影 響; 及三、互惠式教學對學生溝通能力之影響。

\section{一. 互惠式教學對於學生學習排球的興趣之影響}

在課堂中學生初時都比較被動, 而且行動緩慢, 彷佛對 上課的興趣並不大。從以下田野觀察可知：

「同學們都是很慢的跑步熱身。老師在講解的時候, 她們 都不是太專心, 有些在玩弄手指, 有些跟同伴低聲談天。 而老師所指示的項目, 她們都是很漫不經心地, 完全不積 極, 隨隨便便做完動作便算。」(田野筆記)

然而, 學生初時反應冷淡, 可能因為她們過往上的體育 課都是由老師主導, 她們對這種模式已經感到非常厭倦, 從 訪談中她們有以下感受:
「我覺得還可以! 因為以前我在學校的時候是不會這樣, 即老師不會教得那麼細心, 以前都是隨便教, 我們按老師 指示去做他的項目就可以了!」(同學壬, 訪談)

「還可以! 因為我們學校的老師都只是安排我們去適當的 地方後自己練習, 之後大家不會有甚麼合作, 或者一起練 習。」(同學癸, 訪談)

從訪談中, 可知道她們過往的體育課都是以傳統方式進 行、由老師主導, 老師要求她們做甚麼, 她們只跟隨, 這使 學生們對這種上課方式感到厭倦。這正如蔡宗達（2004）指 出傳統教學方式使學生對上體育課的興趣大大降低。由於以 往的模式令學生缺乏動力, 學生對於新的教學模式顯然覺得 有新鮮感, 並有正面的回應：

「當然喜歡這樣。…比以往有趣了很多。」(同學乙, 訪 談)

\section{「我覺得十分新鮮!」(同學己,訪談)}

部份學生是接受與喜歡互惠式模式上課的, 並覺得是很 新鮮。這會使她們更有興趣去學習, 正如張春興（1997）指 出學生面對新鮮的事物, 都有很大的好奇心, 會有更大興趣 去接觸。

「喜歡! 這樣會比起以前, 只是老師教授, 然後我們跟隨 他的指示去練習, 好得多, 而練習又不知其目的是甚麼, 其實現在我們一組組去練習, 即在這裡這樣打球, 這樣 會清楚自己在做甚麼, 同學又會提點及教我多次。」(同學 庚, 訪談)

「同學很迅速地按老師的指示去做相關的項目。在老師的 鼓勵下, 同學都顯得更積極提出回瞶。同學會在旁觀察同 學的動作,並給予回饋。」(田野筆記)

可見這樣的教學模式能給予她們清哳的目標, 使她們清 楚自己練習甚麼, 故她們更有動機去學習, 學習興趣亦得以 提升。這正如Charles（2008）指出為學生提供更清晰的學習 目標, 能使學生更有學習動機。

「我覺得十分新鮮! 以前的體育堂都只是聽從老師的指 示, 由他教授我們。採用這個方法上課去學習、去上體育 課, 大家又多了溝通, 氣氛又熱鬧了很多! 還有我自己覺 得對體育這方面, 這些教學方法是很有幫助的!」(同學 己, 訪談)

「同學在課堂中不時與同伴説話, 不過多為閒聊, 並不關 於練習, 但氣氛融洽。但在老師鼓㺃下, 同學都能簡單説 出同學動作效果是怎麼樣, 如：『好』、『不錯』等」(田野 筆記) 
從學生的感受及課堂觀察可知這樣的模式對於學生的學 習是正面的, 並能增加她們在課堂中的溝通, 使課堂氣氛更 好, 提升她們學習興趣。周朱瑞華（2003）指出良好的學習 氣氛, 能協助學生在堂上學習。

學生對互惠式教學模式的印象都是正面的。研究者曾 在訪談中直接問及學生對採用互惠式教學之意見, 得到的回 應可以分為兩種類型：第一類型為「喜歡」，如「鍾意」、 「緊係鍾意」、「都鍾意嘅」; 第二類型為「一般喜歡」, 如「可以嘅」、「 $\mathrm{ok}$ 嘅」。

其實，大部分受訪者的回應都是第一類型，只有數位 受訪者的回應是第二類型, 而且第二類型的回應並沒有貶意 存在, 可見她們都接受這個教學模式, 大部分人都喜歡這模 式上課。Mizios和Digelidis（2007）指出互惠式模式比傳統教 學更能提升學生的學習興趣, 並於學習運動技巧有更好的效 果。

然而, 學生對於互惠式模式有正面的感受, 亦享受這 模式所帶來的樂趣。比以往傳統由老師主導的教學, 互惠式 教學令同學更積極學習排球。雖然過往的研究很少提及互惠 式教學與學習興趣的關係, 不過這亦不難猜到該模式對學習 興趣的影響。根據自主理論, 當學生擁有更多的自主權的時 候, 她們會有更高的動力 (Vallerand, Pelletier, \& Koestner，2008）。而互惠式教學明顯地將學習權下放於學生身 上, 當學生感到有更多的自主權時, 自然會更有動力去上 課。

另一方面, 根據互動理論（Interactionist Theory）, 人類是需要互動, 才會有意義, 如缺乏互動, 就沒有意義 (Coakley，2003）。在此學習模式下學生之間的溝通多 了, 亦多了同學一起練習, 這樣表示了她們的互動也多了。 學生間的互動多了, 她們上課覺得更有意義, 這令她們更有 興趣上課。這兩個理論所言剛好解釋了實驗課所得出來的結 果。還有一點就是, 人類的學習行為, 大多透過觀察及模仿 而得來的, 而他們最常模仿的對象是其身邊的重要他人, 即 父母、老師等（張春興，1997）。故青少年會喜歡模仿成年 人, 在互惠式模式下, 學生需要給予同伴回饋, 扮演著「小 老師」的角色, 這樣便能滿足她們能模仿成年人的需求, 使 她們更有興趣上課。

\section{二、互惠式教學對學生協作能力之影響}

為了解互惠式教學對學生協作能力之影響, 在實驗課開 始前, 32位學生都需要填寫一份與協作能力有關的學習者分 析表 (許磊, 2008), 主要用作了解學生在互惠式教學開始 前其協作能力水平。而在實驗課後, 亦需要再次填寫, 用以
找出在實驗課對其能力的影響。學生協作能力前後測試結果 見表2：

表 2 : 學生協作能力前後測之統計資料

\begin{tabular}{lccccc}
\hline \hline & 統計量 & 最大值 & 最小值 & 平均值 & 標準差 \\
\hline 協作能力前測 & 32 & 41 & 12 & 29.44 & 5.685 \\
\hline 協作能力後測 & 32 & 45 & 23 & 33.97 & 4.540 \\
\hline \hline
\end{tabular}

表2顯示在前測時, 學生協作能力的最低分數是12分, 最高分數是 41 分, 而平均分是 29.44 分。至實驗課後, 最低分 數提高了11分, 最高分數則增長至 45 分, 而平均分是 33.97 分。學生協作能力前後測比較結果見表3：

表 3 : 學生協作能力前後測之比較 - 相依樣本的 $\mathrm{t}$ 檢定

\begin{tabular}{llll}
\hline \hline & 平均差 & $\mathrm{t}$ 值 & 顯著度 \\
\hline 協作能力 前測 - 後測 & -4.531 & $-3.003^{*}$ & .005 \\
\hline \hline
\end{tabular}

*顯著度設於低過 .01

表3顯示學生協作能力前後測是有顯著差異 $[\mathrm{t}(31)=-$ 3.003， p < .005]，這亦表示學生經過互惠式教學後其協作能 力是有所提升。在訪談中, 所有受訪者不約而同回答與同學 間的合作是多了。這與協作能力分析的結果相配合, 亦與 Donnelly（2002）研究指出互惠式模式能發展學生間之合作 互動的結果吻合。在互惠式教學下，學生有更多與人協作的 機會 :

「老師指示她們去拿取用具時, 不是全組出去拿取用具, 每組會指派一、兩位的同學一起去拿取用具。大部分同學 會幫助練習者練習技術, 如 : 為練習者拋球以作練習。當 練習者把球打走,同學會為她拾球。」(田野筆記)

學生在課堂中分工合作拿取工具和拋球協助練習等, 這全是協作的表現。不過, 陳錦雄（2001）指出體育課能經 常提供學生協作的機會, 而筆者認為上述協作的表現正正是 於一般的體育課經常出現的, 並不完全只是互惠式模式而擁 有。那麼互惠式學習能提升甚麼協作表現呢?

「我們幾位同學分成一組。然後幾位同學分為一 組, 然後我練習的時候, 而其他同學在旁邊觀察、 給予我意見, 就是這樣我們輪流做不同的角色。」 (同學己, 訪談)

「如果那位同學的動作做錯的話, 我會將我懂得的球 技教授她。」(同學乙, 訪談) 
互惠式學習能提供機會學生在課堂分工合作，輪流做練 習者及觀察者的角色, 幫助其同伴練習技術及給予回饋。另 外，學生亦會將技術教授予同伴。簡言之，學生在課堂上擔 任「小老師」的角色, 協助同伴學習。這不但減輕教師的工 作量, 更重要的是提供學生更多協作機會。Jackson和Dorgo （2002）指出互惠式教學能減輕教師的教學負擔, 推動學生 與同伴合作及學習。更重要的是學生的協作不是簡單的體力 勞動, 而是另一個層面的協作, 這需要思考和溝通。這樣, 學生的協作能力得到提升。

「初時, 有些同學未能幫助同伴抛球, 只顧著自己打球, 對 於同伴的動作一言不發。後來, 同學大都自動自覺為同伴 拋球, 在同學展示技術後, 給予回饋。而且同學們在練習 中, 出現很多歡笑聲, 氣氛融洽。」(田野筆記)

「我們之前還説不上怎麼樣合作。但熟了後, 做甚麼事情都 一齊做, 你有些不會, 你可以問同學, 人家同學不會的, 就 會問我。這樣子, 我覺得現在的朋友比之前的多。」(同學 壬, 訪談)

「合作當然是好了, 還有我們的關係都好了, 因為一隊人這 樣才可以達到某一個目的, 譬如老師叫我們連續做五十次 上手傳球, 即是我們可以為了一個目的而一齊努力, 大家 都合作得好好, 關係亦都改善了。」(同學庚, 訪談)

學生在互惠式教學下，不但協作的機會多了，而同伴間 的關係亦有所增進。在同學間協作的時候, 亦是她們與人相 處的時候, 同學間相處多了, 自然與同伴有更多了解, 故同 學間之關係亦大有改進。Garn和Byra（2002）亦指出互惠式 教學能有助學生的社交發展。更重要的是學生間的協作程度 不只流於最表面的給予指導、幫忙撿球等，她們更會有更深 層次的交流，如在課堂練習時懂得鼓勵同伴：

「跟她説：「你打得真好呀!」。」(同學丁, 訪談)

$\lceil\cdots$ 會説「加油」這樣子。」(同學龙, 訪談)

「叫她加油, 問她那個動作是怎樣做的。」(同學癸, 訪談)

「少數同學還會對同伴作出鼓勵, 如 : 説出『加油』、『繼 續打好 d』、同學會為能做到要求動作的同伴鼓掌等。」 (田野筆記)

學生們除了給予同伴回饋, 更懂得欣賞別人而作出鼓 勵, 這是更高層次的交流表現, 亦有助學生的社交發展, Mosston 和 Ashworth (2002) 指出在互惠式模式下同學需 要提供回饋予同儕, 表達多一些同理心, 給予更多讚賞與鼓 勵, 能夠改善學生的社交發展。
很明顯，互惠式教學法能夠提供一個平台予學生，讓 學生得到更多協作機會，從而在協作過程中鍛鍊社交技巧， 對學生的社交發展是很有幫助。與此同時, 學生協作的機會 多了, 也能促進她們的協作能力。當然, 體育課本身都有著 很多讓學生協作的機會, 不過那些協作不外乎分工合作地拿 取用具、拋球、撿球等。然而, 在互惠式模式下教師將學習 權下放, 讓學生在課堂中負起更多責任、角色, 需要她們互 相給予同伴回饋, 鼓勵同伴, 這些全都是較高層次的協作表 現。

\section{三、互惠式教學對學生溝通能力之影響}

同樣地, 為了解互惠式教學對學生溝通能力之影響, 在 實驗課開始前, 32位學生都需要填寫一份與溝通能力有關的 學習者分析表 (許磊, 2008)，主要用作了解學生在互惠式 教學開始前其溝通能力水平。而在實驗課後, 她們再填寫多 一次, 用以找出在整個實驗課後對其溝通能力的影響。學生 溝通能力前後測試結果見表4：

\section{表 4 : 學生溝通能力前後測之統計資料}

\begin{tabular}{lccccc}
\hline \hline & 統計量 & 最大值 & 最小值 & 平均值 & 標準差 \\
\hline 溝通能力前測 & 32 & 37 & 16 & 25.56 & 5.582 \\
\hline 溝通能力後測 & 32 & 40 & 22 & 30.34 & 4.352 \\
\hline \hline
\end{tabular}

表4顯示在前測時, 最低分數為16分, 而最高分數是37 分, 平均分是 25.56 分。至後測時, 最低分數提高了6分, 最 高分數則增長至40分, 而平均分是30.34分。學生溝通能力前 後測比較結果見表 5：

表 5: 學生協作能力前後測之比較-相依樣本的 $\mathrm{t}$ 檢定

平均差 $\mathrm{t}$ 值顯著度

溝通能力 前測 - 後測 $\quad-4.781 \quad-3.841 * \quad .001$

*顯著度設於低過 .01

表 5 顯示學生溝通能力前後測是有顯著差異 $[\mathrm{t}(31)=-3.841$, $\mathrm{p}<.001]$ ，這亦表示學生經過互惠式教學後其溝通能力是有所 提升。此外, 訪談內容中亦顯示溝通機會有所增長。被問及 學生間溝通情況時, 所有受訪者不約而同回答與同學間的溝 通多了。如張春秀（2004）指出在互惠式教學下學生會有更 多回饋及溝通的機會。在互惠式教學下，學生確實有很多與 人溝通的機會 : 
「同學在課堂中不時與同伴説話, 不過只是閒聊, 並不 關於練習, 如：『午飯你會去哪裡吃?』『你做完功課沒 有?』。不過有同學會認真給予同學回饋, 如: 在同學做畢 動作後,會説出同學欠缺甚麼技巧。在老師鼓勵下, 同學 都更自動自覺地為練習者給予回饋。(田野筆記)

周朱瑞華（2003）指出學生在課堂經常出現與人談天的 情況。更何況互惠式教學要求學生提供回饋, 造就學生有很 多的溝通機會。

「我學懂了怎樣打排球, 但不是很属害。但跟我不 同班的同學溝通多了, 還有新的話題。...即研究 一下其他平日的閒事。」(同學戊, 訪談)

「我覺得我比以前膽量大了很多。即是比以前我更 勇於跟別人溝通……家都十分樂意給我回瞶, 告訴我練習該技術時有甚麼不妥的地方」(同學 己, 訪談)

「溝通! 溝通當然是多了, 因為大家一起打球這樣, 即是同學會告訴我有甚麼地方做得不太好, 或者有 甚麼地方做得很好, 這樣便可以知道自己做過了甚 麼, 做得好的地方及做得不好的地方。」(同學庚, 訪談)

學習時, 學生們都願意與同伴溝通, 又會給予回饋, 她 們之間的溝通比以往多, 這都是因為互惠式教學要求學生提 供回饋, 是一般課堂較少出現的, 所以學生在互惠式教學下 會比一般課堂有更多溝通。這與Chatoupis (2009) 研究指出 互惠式教學能增加學生的口語互動的結果吻合。

「初時, 同學大多不會給予回饋, 只是在練習技術動作。 同學練習完畢, 就輪到下一個。對於技術動作, 都一言不 發。在老師鼓勵下, 同學開始提供回饋, 如：『好』、『不 錯』、『非常一般』, 這都是一般回饋。」(田野筆記)

研究者從觀察中亦發現, 雖然互惠式教學法能夠提供 一個平台予學生社交互動的機會, 不過要使她們利用「提供 回饋」這種形式去互動, 還需要老師提供協助, 如加上老師 的鼓勵和指導, 效果便慢慢浮現出來。故教學法只是一個形 式, 真正的催化劑是教師。教師的角色是非常重要的, 但不 是要主導課堂所有東西。如李世光 (2008) 指出整個的教學 法只是一個形式, 真正令它活化和發揮功效, 其實是老師的 催化, 故老師於課堂教學中扮演重要的角色。

「我們的合作應該可以説沒有問題的, 因為每個人的溝通 都多, 隨後就明白其他人多了。」(同學癸, 訪談)

「雖然有些麻煩, 經常都要看著同伴的動作, 不過都喜 歡的。即是大家熱鬧了很多、融合了很多。」(同學癸, 訪 談)
學生間的溝通多了之同時, 她們的關係亦有改進, 因為 她們協作與溝通的機會多了, 同學間的互動得以增加, 更了 解對方, 她們的關係亦因而有所改進。正如Ernst 和 Byra （1998）在其研究中指出給予及收取回饋對於學習者是一個 正面的經驗, 協助其社交發展。而Cleland（2002）都指出這 樣的模式對於學生與人相處及交朋友技巧都有正面的影響。 學生間之溝通除了數量上有所增加外, 她們溝通的質素亦有 一定提升, 當被問及她們對同伴的意見怎樣看法時, 有以下 回應 :

「還有於表達能力這方面都清晰了很多。…雖然有時都 十分含糊地表達東西, 不過都看到大家都是正在進步中 的, 即是大家都十分樂意給我回饋, 告訴我練習該技術時 有甚麼不妥的地方。」(同學己,訪談)

「很多都是合理的。…明白的。因為日常會一起聊天的都 是那些人。」(同學戊, 訪談)

「我覺得因為大家都知道正在做甚麼, 老師又説過怎樣 做, 其實所以都知道。都合理的, 因為她們知道譬如 out ball不要接, 接著會大聲『唉! out ball』, 接著就不接球 這樣。」(同學庚, 訪談)

學生給予同伴的意見大致合理及清晰, 令同伴清楚明 白。這證明學生們溝通是有一定的質素, 而且在課堂學習 中, 此等質素亦慢慢改善及進步。從觀察所得, 更有以下發 現 :

「有時候, 同學會直接在練習者旁邊展示整個動作一次。 有時候, 同學以伸直的手來指示練習者做動作時應該把 手伸直。有些同學會一邊提供口頭回饋, 一邊還會示範動 作。有些同學更會捉著同學的手去練習動作。」(田野筆 記)

同學不但説話合理清哳, 更會使用非口頭洅通 (身體語 言）, 如：親身示範。有些同學提供回饋時, 更會同步展示 口頭溝通及非口頭溝通。可見互惠式教學能幫助學生發展溝 通能力, Goldberger (2006) 的研究亦指出互惠式模式能 改善學生與同伴互動及溝通技巧。至於回饋內容方面, 研究 者發現學生漸進地改變 :

「初時, 同學大多不會提供回饋。而經教師的鼓勵 後, 開始説『好』、『非常一般』、『不錯』等一般的 回饋。再由教師的指導下, 同學開始説『腳部有問 題』、『手部不好』等指出甚麼部分有問題。隨後, 同學能夠説出『腳要前後站』、手不夠直』等更仔細的 回饋。」(田野筆記) 
學生的回饋質素是不斷的提升。由初時只能提供一些 很簡單的回瞶, 及至最後能呴較具體説出同伴動作錯誤處。 這亦表示學生表達及與人溝通的能力都在進步。不過, 當中 發現學生是需要教師的提點鼓勵, 由最簡單的回饋去到較 高層次的回饋, 需時間協助才有較好的回饋效果。正如Byra （2004）指出互惠式教學需要循序漸進地去實行, 不能一步 登位的。

「我覺得有時候比老師講得還要明白。…因為她們講解 的時候。…沒有那麼深奧。」(同學癸, 訪談)

有受訪者更指出與同伴溝通是沒有問題的, 因為同伴 的説話沒有老師那麼深奧。這裡顯示出有時學生與同伴間之 溝通會比老師與學生的溝通來得更直接和清晰。故由學生負 責給予同伴回饋的其中一個優點是她們會更容易接受。正如 Jackson和Dorgo（2002）指出同學較易明白由同學而來的回 饋。其實, 這裡也值得各老師反思, 究竟老師與學生溝通的 效能是如何呢? 老師的用語的合切性又如何呢?

總括而言, 在互惠式模式下學生協作的機會多了, 使她 們溝通的機會也多了, 因而得到鍛鍊溝通技巧的機會, 幫助 社交發展。再藉著溝通多了, 亦促進學生間之了解, 使學生 間之關係有所增進。雖然是次研究並沒有去考究學生所給予 的回饋的準確性, 但是研究結果顯示學生得到的回饋比以往 多, 因為回饋不只由老師給予, 還有由同學而來的, 並且同 伴的回饋對於她們來説會更易掌握及接受, 這對學生的學習 有一定的作用與幫助, 這與Donnelly（2002）研究發現同硛 學習會會隨著個人化的指導、回應機會及回饋的提供等方面 增加，會提升學習者之學習效果吻合。

\section{結論}

本研究的限制是參與者的人數不夠多及廣, 故其代表性 受到一定的影響。雖然代表性並不強, 但是本研究所得的結 果都值得大家去參考。在日後的體育教學中, 老師亦應嘗試 這種教學模式。而研究中的教學內容只是球類運動, 對於其 他運動教學是否同樣適合採用就存有一定的疑問。至於受試 者只是一個性別, 故並不可以代表兩個性別的學生都有同樣 效果。
研究當中不難發現學生們對於傳統的上課模式已經感 到厭倦, 互惠式教學讓她們於學習中得到更多自主權, 使她 們更有目標、興趣去參與課堂活動。是次實驗課的學習內容 跟平常的並沒有甚麼分別, 只是在學習型式上轉成互惠式, 但對於學生的學習興趣之效果已經立竿見影, 這表示如果教 師肯花點心思, 其實課堂學習會有很不同的效果 (夏書宇, 2008）。

互惠式教學法能夠提供一個平台予學生, 讓學生得到更 多協作的機會, 從而在協作的過程中鍛鍊她們的社交技巧, 對學生的社交發展是很有幫助。這樣學生的協作能力亦有所 提升。

在此模式下學生協作的機會多了, 她們溝通的機會也多 了, 一來藉此得到鍛鍊溝通技巧的機會, 幫助社交發展, 二 來藉著涶通多了, 亦促進學生間之了解, 使學生間之關係有 所增進。而且由學生給予回饋的好處是她們會更易接受和得 到更多回饋。

綜合以上，互惠式模式無論對於學生的學習興趣、協 作能力及溝通能力都有著正面的影響。比起傳統上課模式, 學生更喜歡採用互惠式上課, 而其學習興趣得以提升。至於 學生的協作能力及溝通能力方面, 都是有所提升的。不過, 更重要的是此模式提供一個平台予學生去鍛鍊他們的共通 能力。而學生能透過此學習過程, 發展其人際關係。最後, 整個的教學法是一個形式, 真正令它富有生命力、發揮功效 其實是老師, 因此老師在課堂內仍然扮演重要的角色 (李世 光, 2008）。

\section{後續研究之建議}

是次研究受試者只有來自於同一間學校的同一班 32 人的 學生, 受試者不夠廣泛, 故研究者建議日後用更多不同的受 試者來研究, 增加其代表性。其次, 是次研究只對女生作出 探討, 日後研究可嘗試以不同性別的組合來測試互惠式教學 法對共通能力的影響。

還有, 是次研究只針對排球教學, 日後研究可以嘗試其 他拍類/球類運動, 還有其他的運動項目教學是否適合使用 這方法。最後, 對於互惠式教學法, 本研究只探討了互惠式 教學法對協作能力及溝通能力之影響, 而其他的共通能力並 沒有一一探討, 日後的研究可嘗試探討此教學法對其他共通 能力之影響, 如: 審美能力、解難能力、批判能力等。 


\section{參考資料：}

Beveridge, R. M., \& Berg, C. A. (2007). ParentAdolescent collaboration: An interpersonal model for understanding optimal interactions. Clinical Child and Family Psychology, 10(1), 25-52.

Byra, M. (2006). The reciprocal style of teaching: A positive motivational climate. Paper presented at the AIESEP World Congress: The Role of Physical Education and Sport in Promoting Physical Activity and Health, Jyväskylä, Finland.

Byra, M., \& Marks, M. (1993). The effects of two pairing techniques on specific feedback and comfort levels of learners in the reciprocal of teaching. Journal of Teaching in Physical Education, 12(3), 286-300.

Charles, C. M. (2008). Building classroom discipline. Boston, Mass.: Pearson/Allyn and Bacon.

Chatoupis, C. (2009). Contributions of the spectrum of teaching styles to research on teaching. Studies in Physical Culture and Tourism, 16(2), 193-205.

Cleland, F. E. (2002). The Spectrum connection: Assessment, social responsibility, and critical thinking. Teaching Elementary Physical Education, 14(5), 10-13.

Coakley, J. J. (2003). Sport in society: Issues \& controversies. Boston, Mass.: McGraw-Hill Education.

Donnelly, F. C. (2002). The spectrum connection: Assessment, social responsibility, and critical thinking. Teaching Elementary Physical Education, 13(4), 10-13.

Ernst, M., \& Byra, M. (1998). Pairing learners in the reciprocal style of teaching: Influence on student skill, knowledge, and socialization. Physical Educator, 55(1), 24-37.

Fraenkel, J. R., \& Wallen, N. E. (2003). 楊孟麗、謝水南譯。 教育研究法: 研究設計實務。台北: 美商麥格羅·希爾國際 股份有限公司。

Garn, A., \& Byra, M. (2002). Psychomotor, cognitive, and social development spectrum style. Teaching Elementary Physical Education, 13(2), 8-13.
Goldberger, M. (2006). Effects of reciprocal teaching on skill on skill acquisition, cooperation, and ability to analyze in fifth grade children. Paper presented at the fourth annual CISAT Faculty Research Day, James Madison University, VA.

Gratton, C., \& Jones, I. (2004). Research methods for sport studies. London: Routledge.

Jackson, J. A., \& Dorgo, S. (2002). Maximizing learning through the reciprocal style of teaching. Teaching Elementary Physical Education, 13(2), 14-18.

Mizios, D., \& Digelidis, N. (2007). Motivational climate, intrinsic-extrinsic motivation and teaching styles: The reciprocal and self-check style. Paper presented at the 12th European Congress of Sport Psychology, Chalkidiki, Greece.

Mosston, M., \& Ashworth, S. (1994). Teaching physical education $\left(4^{\text {th }}\right.$ ed.). New York: Macmillan College Publishing Company.

Mosston, M., \& Ashworth, S. (2002). Teaching physical education $\left(5^{\text {th }}\right.$ ed.). San Francisco, CA: B.Cummings.

Patton, M. Q. (2002). Qualitative research and evaluation methods ( $3^{\text {rd }}$ ed.). Thousand Oaks, Calif.: Sage Publications.

Reppa, G. P. (2007). Motivation and affective outcomes of physical education: implications for health education. Science Education International, 18(3), 217-233.

Sherman, M. (1982). Style analysis checklist for Mosston's spectrum of teaching styles. Unpublished manuscript, University of Pittsburgh.

Strauss, A. L., \& Corbin, J. (1990). Basics of qualitative research: Grounded theory, procedures and technique. Newsbury Park: Sage Publication.

Vallerand, R. J., Pelletier, L. G., \& Koestner, R. (2008). Reflections on self-determination theory. Canadian Psychology, 49(3), 257-262. 
王文科 $(2000)$ ○質的教育研究法。台北, 師大書苑有限公司。

李世光 $(2008)$ • 新形勢下體育教師的角色定位。內蒙古電大學 刊, 9, 112-113。

李曉風、余雙好 $(2006)$ 。質性研究方法。武漢市, 武漢大學出 版社。

周朱瑞華 (2003) • 有效課室管理70式。香港, 香港教育圖書公 司。

周宏室 (1994) ${ }^{\circ}$ Mosston(摩斯登)體育教學光譜的理論與應用。 台北, 師大書苑有限公司。

姚愛梅 (2008)・初中生學校交往現狀及心理分析。中國蘇州大 學專業學位論文, 未出版。

陳錦雄 (2001): 體育教學 輯於陳錦雄、李宗、高達倫、蔡謝鏡 珍、曾卓權和黄志德編著, 中學體育課程範本, (頁1-38)。 香港, 香港教育學院。

夏書宇 $(2008)$ • 新課標形勢下體育教師多重角色定位的思考。 河南工業大學學報(社會科學版), $4(2), 138-140$ 。

張春秀 (2004) ${ }^{\circ}$ Mosston教學光譜 - 互惠式教學策略。國教 世紀, 213, 15-20。

張春興 (1997)。教育心理學。台灣, 東華書局。

許否 (2008)。通過綜合實践活動課培養學生的合作意識與 溝通能力。華東師范大學教育資訊技術系碩士論文, 未出 版。
課程發展議會 (2001)。學會學習: 終身學習, 全人發展。香港, 政府印務局。

課程發展議會 (2002)。體育 一 學習領域課程指引 (小一至 中三)。香港,政府印務局。

課程發展議會 (2005)。體育學習成果架構。香港, 政府印務 局。

蔡宗達 (2004) • 理解式球類教學法與技能取向球類教學法比 較研究。國立台灣師範大學體育學系碩士論文, 未出版。

謝旭洲 (2008) • 社會統計與資料分析。臺北縣深坑鄉, 威仕曼 文化事業有限公司。

\section{Correspondence:}

聯絡人: 高達倫博士

Contact Person: Dr. Alberto Cruz

Phone: (852) 29487847

Fax: (852) 29487848

E-mail: acruz@ied.edu.hk

Address: 香港新界大埔露屏路十號 香港教育學院健康與體育學系 Department of Health \& Physical Education The Hong Kong Institute of Education 10 Lo Ping Road, Tai Po, New Territories, Hong Kong 